Canadian

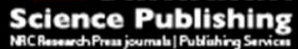

Canadian Journal of Physiology and Pharmacology Revue canadienne de physiologie et pharmacologie

\title{
Characterization of the peristaltic reflex in murine distal colon
}

\begin{tabular}{|r|l|}
\hline Journal: & Canadian Journal of Physiology and Pharmacology \\
\hline Manuscript ID & cjpp-2015-0086.R2 \\
\hline Manuscript Type: & Article \\
\hline Date Submitted by the Author: & 03-Jul-2015 \\
\hline Complete List of Authors: & $\begin{array}{l}\text { Zhang, Yong; Queen's University, GIDRU } \\
\text { Paterson, William; Hotel Dieu Hospital, Queen's University, Medicine }\end{array}$ \\
\hline Keyword: & $\begin{array}{l}\text { Smooth muscle, Descending inhibition, Ascending excitation, Intracellular } \\
\text { recordings, Balloon distension }\end{array}$ \\
\hline
\end{tabular}

\section{SCHOLARONE \\ Manuscripts}


Characterization of the peristaltic reflex in murine distal colon

\title{
Yong Zhang $^{1}$ and William G Paterson ${ }^{2}$
}

\begin{abstract}
Gastrointestinal Diseases Research Unit ${ }^{1,2}$ and Departments of Biology ${ }^{2}$, Biomedical and Molecular Sciences ${ }^{2}$, and Medicine ${ }^{2}$, Queen's University and Kingston General Hospital, Kingston, Ontario, Canada
\end{abstract}

Correspondent author: Dr. William G. Paterson, Division of Gastroenterology, Hotel Dieu Hospital, 166 Brock St., Kingston, Ontario, Canada, K7L 5G2. Tel: +1 613 544-3400 Ext. 3376. Fax: +1 613 544-3114. e-mail: patersow@hdh.kari.net

Abbreviations: BD: Balloon distention; IJP: inhibitory junction potential; EJP: excitatory junction potential; RMP: resting membrane potential; CSM: circular smooth muscle; NS: nerve stimulation; L-NAME: Nw-nitro-L-arginine methyl ester hydrochloride; MRS-2179: 2' -Deoxy-N6-methyl adenosine 3' ,5' -diphosphate diammonium salt; MRS-2500:(N)-Methanocarba-N6-methyl-2-iodo-2'deoxyadenosine-3',5'-bisphosphate; NOS: nitric oxide synthase; GI: gastrointestinal. 


\begin{abstract}
Ascending and descending neuromuscular reflexes play an important role in gastrointestinal motility. However, the underlying mechanisms in colon are incompletely understood. Nerve stimulation (NS) and balloon distention (BD)mediated reflexes in distal colonic circular and longitudinal smooth muscle (CSM; LSM) of mice were investigated using conventional intracellular recordings. In the CSM, NS evoked ascending purinergic inhibitory junction potentials (IJP) whereas BD induced atropine-sensitive ascending depolarization with superimposed action potentials (APs). The ascending depolarization reached a peak $\sim 4-7$ seconds after the onset of distention and gradually returned to baseline after termination of the distention. In the LSM, NS produced an ascending biphasic IJP followed by a train of atropine-sensitive APs. Both stimuli produced similar descending IJPs in CSM and LSM, which were blocked by MRS-2500 and MRS-2179, putative purinergic receptor blockers. These data indicate that in the murine distal colon descending purnergic inhibition to both CSM and LSM occurs. Ascending responses are more complex, with NS producing both inhibition and excitation to CSM and LSM, and BD evoking only cholinergic excitation.
\end{abstract}

Key words: Descending inhibition; Ascending excitation; Smooth muscle; Intracellular recordings; Balloon distension. 
Introduction

Motility of mammalian gastrointestinal (GI) tract is characterized by coordinated propagating waves of smooth muscle contraction and relaxation, also known as peristalsis, that serves to propel gastrointestinal contents aborally (Goyal and Paterson 1989). The "law of the intestine", described over a century ago by Bayliss \& Starling (Bayliss and Starling 1899, 1900) in canine small and large intestine, remains the core concept of our understanding of the peristaltic reflex. They demonstrated that local mechanical stimulation of the gut produced excitation above and inhibition below the stimulation site, which was controlled by the intrinsic nervous system (Bayliss and Starling 1899).

Subsequent observations on ascending excitation and descending inhibition have been somewhat inconsistent. Early intracellular recording studies in guineapig ileum demonstrated that short latency transient inhibitory junction potentials (IJPs) in the circular muscle layer followed by excitatory junction potentials (EJPs) were evoked by balloon distention of intestinal segments in both the circular and longitudinal muscle layers (Hirst et al. 1975), but only on the anal side of the stimulated region of intestine (Hirst and McKirdy 1974). On the other hand, more recent tension recording studies have suggested that guinea-pig ileum does not obey the 'law of the intestine' (Spencer et al. 1999). Both oral and anal stimuli elicited a contraction that occurred synchronously in both the circular and longitudinal layers. 
To date, studies on the colonic peristaltic reflex have focused predominantly on the CSM and, depending on the species and region of the colon studied, have reported that descending inhibition is mediated by purinergic, nitrergic or VIPergic neurotransmission, whereas ascending excitation appears to involve cholinergic and tachynerigic neurons (Ciccocioppo et al. 1994; Grider and Makhlouf, 1986; Hata et al. 1990; Spencer and Smith 2001;). There has yet to be a systematic evaluation of these ascending and descending reflexes in response to electrical and mechanical stimuli in both CSM and LSM concurrently.

The current studies using distal colon of mice were designed to answer the following questions: 1) Does the murine distal colon obey the "law of the intestine" in both circular and longitudinal smooth muscle layers and if so, which neurotransmitters mediate ascending excitation and descending inhibition?; 2) Are junction potentials produced by nerve stimulation comparable to those evoked by distention? Part of these results have been published in an abstract form (Zhang and Paterson 2011). 
Methods

\section{Animal preparation:}

All animal procedures were approved by the Animal Care Committee of Queen's University. WBB6F1 $\mathrm{J}^{(++)}$homozygous mice were used. All mice were purchased from Jackson Laboratories (Bar Harbor, Maine, USA). Mice of either sex, aged between 8 - 12 weeks and weighing between 20 - 40 g, were killed by decapitation following isoflurane anesthesia. The distal colon $(\sim 2 \mathrm{~cm})$ was removed en bloc via an abdominal incision.

Distal colon preparation and conventional intracellular recordings (Fig 1):

Using a dissecting microscope, the distal colon was dissected free from attached tissue and the mucosal layer removed. The anal end $(\sim 0.6-0.8 \mathrm{~cm})$ was cut open to study descending inhibition, whereas oral end was opened to study ascending excitation. Strips of the open distal colon were pinned with mucosa side facing upward on the bottom of a recording chamber covered by Sylgard (Dow Corning) for intracellular recording from the CSM, while it was pinned with mucosa side facing downward for intracellular recording from the LSM. Tissue preparations were perfused at $2 \mathrm{ml} \mathrm{min}^{-1}$ with pre-oxygenated Kreb's solution preheated to $36^{\circ} \mathrm{C}$. A lab-made latex balloon $\sim 0.8 \mathrm{~cm}$ in axial length and attached to a $40 \mathrm{~cm}$ plastic tube was placed in the lumen of the unopened segment of the distal colon, and a pair of transmural NS electrodes were positioned between the balloon and recording sites. Responses to nerve 
stimulation (NS; 4 square wave pulses, each 0.3 ms duration, $20 \mathrm{~Hz}$ ) and graded balloon distention $(\mathrm{BD})(0.05,0.10,0.15$ and $0.20 \mathrm{ml}, 10 \mathrm{~s})$ were recorded using conventional intracellular electrodes as previously described (Zhang and Lang 1994; Zhang and Paterson 2002) and balloon pressure was simultaneously monitored using a pressure transducer (Figure 1.)

\section{Solutions and Drugs:}

The modified Kreb's solution contained the following (in $\mathrm{mM}$ ): $\mathrm{NaCl} 118.07$, $\mathrm{NaHCO}_{3} 25.00, \mathrm{D}(+)$-glucose $11.10, \mathrm{KCl} 4.69, \mathrm{CaCl} 2.52, \mathrm{MgSO}_{4} 1.00$ and $\mathrm{NaH}_{2} \mathrm{PO}_{4}$ 1.01. All drugs were purchased from Sigma (Burlington, Canada), except isoflurane (Baxter, Canada). The following drugs were used: atropine, nifedipine, $N^{G}$-nitro-L-arginine methyl ester (L-NAME), MRS-2179 and MRS-2500. Nifedipine was dissolved in pure alcohol. All other drugs were dissolved in distilled and de-ionized water. These were then diluted to final concentrations with Krebs' solution.

Statistical analysis:

The following parameters were quantified: resting MP $(\mathrm{mV})$, amplitude $(\mathrm{mV})$ and duration at half amplitude (ms) of both the excitatory and inhibitory junction potentials. Pre- and post-drug comparisons were made using the paired Students $t$-test, and a $P$-value of $<0.05$ was considered statistically significant. 


\section{Results}

1. General electrical properties in distal colonic CSM and LSM.

Consistent with our previous studies (Zhang et al. 2010b), and those of others ( Gil et al. 2010; Spencer et al. 1998), distal colonic CSM demonstrated spontaneous inhibitory junction potentials (IJPs) (Figure 2. A. b). Distal colonic LSM was characterized by both spontaneous and truncated action potentials (APs). The latter had the appearance of spontaneous excitatory junction potentials (EJPs) (Figure 3. A. a). APs were recorded in 9 of 12 preparations of the distal LSM. Nifedipine blocked the APs in all cases tested (Appendix 1), whereas atropine suppressed the APs in 7 of 9 preparations (Figure 3. A. b), suggesting that spontaneous release of acetylcholine produces APs via opening of L-type $\mathrm{Ca}^{2+}$ channels, in keeping with the recent $\mathrm{Ca}^{2+}$ imaging studies in the murine large intestine (Bayguinov et al. 2010). Unlike in the LSM, spontaneous APs were rarely seen in the CSM.

2. Ascending responses to NS and BD in colonic CSM.

Either 1 pulse (PS) or 4 PS NS at $20 \mathrm{~Hz}$ was delivered by a pair of silver wires placed between the balloon and intracellular recording sites. The intracellular recordings were performed in the proximal end of distal colons. Electrical responses to NS and BD were recorded in the same smooth muscle cell for direct comparison. Results are summarized in Table 1. Resting MP averaged 
$-45.4 \mathrm{mV}$. Either 1 or 4 PS produced a monophasic IJP (Figure 2. B). Rebound APs usually followed the IJPs. Atropine significantly potentiated the IJPs evoked by $4 \mathrm{PS}$, but not by $1 \mathrm{PS}$. Unlike NS, tissue graded BD $(0.05-0.20 \mathrm{ml}, 10 \mathrm{~s})$ induced an EJP, which reached a peak $\sim 4-7$ seconds after the onset of distention and gradually returned to baseline after termination of the distention. APs were superimposed on the EJPs (Figure 2. A), both of which were completely blocked by bath application of $3 \mu \mathrm{M}$ atropine (10 $\mathrm{min}$ ). These data from the colonic CSM suggest that the ascending responses to NS and BD are different and that cholinergic innervation mediates the ascending excitation.

Application of MRS-2500 ( $1 \mu \mathrm{M}, 10 \mathrm{~min})$ converted 4PS-induced monophasic IJPs to biphasic IJP complex, a flJP and a sIJP (Figure 2. \& 5. B ). Further administration of L-NAME (200 $\mu \mathrm{M}, 15 \mathrm{~min})$ inhibited MRS-2500-resistant flJP and abolished sIJP (Figure 5. B). These effects of atropine were partially reverse 45 min after washing out.

3. Ascending responses to NS and BD in colonic LSM.

Table $1 \& 2$ summarize the ascending responses to NS and BD in colonic LSM. NS (1 and 4 PS) induced a biphasic IJP consisting of an initial fast IJP (fIJP), followed by a sIJP and then rebound APs in the distal LSM (Figure 3. B). Administration of atropine $(3 \mu \mathrm{M})$ significantly enhanced the amplitude of the flJPs. Rebound APs were not affected by atropine. In the presence of atropine, the selective $\mathrm{P}_{2} \mathrm{Y}_{1}$ receptor antagonist MRS-2500 $(1 \mu \mathrm{M})$ markedly inhibited the 
flJPs and potentiated the slow IJP (Figure 4. B). Addition of the nitric oxide synthase inhibitor L-NAME $(200 \mu \mathrm{M})$ in the presence of MRS-2500 further inhibited the fast IJP and abolished the sIJPs (Figure 5. B. \& Table 1.).

$\mathrm{BD}$ at $0.10 \mathrm{ml}$ produced a brief IJP following by a series of APs during the distention (Figure 3. A. a). Application of atropine blocked the series of APs (Figure 3. A. b). MRS-2500 eliminated the brief IJPs produced by all grades of BD (Figure 4. A. \& B.) and mutant mice LSM (Figure 4. A). These results indicate that the biphasic ascending responses, brief inhibition and sustained excitation, are mediated by purinergic and cholinergic neural pathways, respectively.

4. Descending responses to NS and BD in colonic CSM.

NS (1 PS and 4 PS) evoked a monophasic IJP, following by rebound APs (Figure 6. B. \& Table 3.). Administration of MRS-2500 (1 $\mu \mathrm{M})$ markedly inhibited the IJPs, but further addition of L-NAME $(200 \mu \mathrm{M})$ did not produce significant effects on the residual IJPs, which is similar to our previous studies in CD1 mice (Zhang et al. 2010b). Interestingly, we noted in some experiments that L-NAME induced more rebound APs in the presence of MRS-2500 in CSM (Figure 7).

Table 4 summarizes the data on descending inhibition produced by graded BD. BD provoked a transient IJP during distention followed by rebound APs after balloon deflation (Figure 6. A.). Application of MRS-2500 (1 $\mu \mathrm{M}, 10 \mathrm{~min})$ blocked the descending IJPs, while additional administration of L-NAME (200 $\mu \mathrm{M}, 15 \mathrm{~min})$ 
produced no further effects (Figure 6. A), implying that purinergic innervation plays an important role in the descending inhibition in the distal colonic CSM.

5. Descending responses of distal colonic LSM to NS and BD.

Data on the descending inhibition to LSM produced by NS and BD are summarized in Tables 3. \& 4. Similar to distal colonic CSM, NS (1 and 4 PS) evoked a monophasic IJP following by rebound APs (Figure 8. A), which was not affected by L-NAME (200 $\mu \mathrm{M}, 15 \mathrm{~min})$ (Figure 8. B). Application of the $\mathrm{P}_{2 \mathrm{Y} 1}$ receptor antagonist MRS-2179 $(10 \mu \mathrm{M})$ markedly inhibited the IJPs (Table 3.), while MRS-2500 (1 $\mu \mathrm{M}, 10 \mathrm{~min})$, a more potent and selective $\mathrm{P}_{2 \mathrm{Y} 1}$ receptor antagonist than MRS-2179 (Gallego et al. 2011; Gil et al. 2010; Grasa et al. 2009; Jimenez et al. 2014) abolished the IJPs (Figure 10.).

$\mathrm{BD}$ induced a comparable descending inhibitory response consisting of a transient IJP during the distention following by rebound APs upon balloon deflation (Figure 9). L-NAME $(200 \mu \mathrm{M})$ did not produce any significant effects on these descending responses, whereas subsequent application of MRS-2179 (20 $\mu \mathrm{M}$ ) blocked the descending IJPs and shifted the rebound APs to the beginning of the distention (Figure 9. B).

The effects of L-NAME and MRS-2500 were then tested in reverse order (Figure 10). MRS-2500 (1 $\mu \mathrm{M}, 10 \mathrm{~min})$ abolished the descending IJP produced by NS and BD, whereas subsequent application of L-NAME did not induce any further 
effects. As with the distal colonic CSM, these data are consistent with purinergic nerves being the predominant mediators of descending inhibition produced by both NS and BD in the LSM. 


\section{Discussion}

The current study represents the first comprehensive characterization of the ascending and descending components of the peristaltic reflex in both CSM and LSM of murine distal colon. In general, our findings support the classic concept of the "law of the intestine" as originally described in dogs and rabbits by Bayliss \& Starling (Bayliss and Starling 1899, 1900), but there are some interesting differences between the CSM and LSM responses as well as between NS and BD. In the CSM, BD evokes an ascending cholinergic excitatory response and a descending purinergic inhibitory response. On the other hand, in the LSM, BD evokes a brief ascending purinergic IJP following by cholinergic excitation, and a descending purinergic inhibitory response. With NS, the ascending response to CSM consists of a purinergic IJP followed by rebound excitation, whereas in the LSM the response is triphasic, consisting of a purinergic fast IJP followed by a nitrergic slow IJP and then rebound excitation. Descending responses evoked by NS to both CSM and LSM consist of monophasic purinergic IJPs followed by rebound excitation.

It has long been know that colonic distention induces descending inhibition mediated by nonadrenergic, noncholinergic neurons (Costa et al. 1992; Mancinelli et al. 1983; Tonini et al. 1982). More recently it has been determined that this descending inhibitory neurotransmission is predominantly purinergic, nitrergic or VIPergic, with variations seen depending on the species, muscle layer, 
or region of the colon studied. For instance, in rat proximal colon, balloon distention-induced descending relaxation was blocked by Nitro-arginine, but unaffected by desensitization to ATP, VIP or neurotensin (Hata et al. 1990), whereas in rabbit distal colon the descending relaxation was abolished with a combination of apamin and L-NNA, although the L-NNA effect was minimal (Ciccocioppo et al. 1994). This is similar to what was reported in guinea pig distal colon (Spencer and Smith 2001). They found that the descending IJP was 55\% apamin sensitive with the remainder blocked by L-NAME. On the other hand, in rat and guinea-pig mid colon, antiserum to VIP suppressed the descending relaxation at all grades of stretch in a concentration-dependent manner (Grider and Makhlouf 1986).

In the current study, the descending IJP to CSM induced by both BD and NS was blocked by selective $\mathrm{P}_{2} \mathrm{Y}_{1}$ receptor antagonists, but unaffected by nitrergic blockade. This is in keeping with our previous work (Zhang et al. 2010a; Zhang et al. 2010b; Zhang and Paterson 2010). While there is a significant nitrergic component to the IJP in the more proximal murine colon (Gallego et al. 2012; Hwang et al. 2012), this appears to decrease significantly in more aboral segments (Zhang and Paterson 2010), which is an observation we have also made in human colon (Zhang and Paterson, unpublished observations). The physiological relevance of this is uncertain. A recent study in human colon CSM (Mane et al. 2014) demonstrated that the purinergic IJP is associated with a short phasic relaxation, whereas the nitrergic IJP translates into a slow sustained 
relaxation. This may therefore explain the different motor patterns seen in the proximal versus distal colon (i.e. more rapid phasic relaxations and contractions distally). Nevertheless, it is noteworthy that using purely mechanical recording techniques, others have shown that NO synthase inhibition can partially inhibit the descending relaxation induced by BD in the murine distal colon (Okishio et al. 2005). The reason for this discrepancy is unclear; it could simply relate to differences in tissue preparation, but also could be due to NO-mediated relaxation occurring in the absence of significant hyperpolarization (Christensen et al. 1995).

The only previous study to systematically evaluate the ascending and descending colonic peristaltic reflex in both muscle layers was performed by Spencer and Smith (Spencer and Smith 2001) in guinea pig distal colon. Similar to our study, they found that BD evoked a descending IJP that was followed by rebound depolarization and spike bursts. However, unlike our mouse model where this IJP was antagonized by purinergic blockade in both LSM and CSM, in the guinea pig, the IJP was entirely nitrergic in the LSM, whereas in the CSM it was mediated by both purinergic and nitrergic neurotransmission. In the guinea pig, ascending responses consisted of atropine-sensitive excitation in both CSM and LSM. In the mouse model, cholinergic excitation was also seen in the CSM and LSM, but interestingly, there was an inhibitory component to the ascending response in the LSM. 
Tachykinins have been reported to play a role in ascending excitation in the rat colon (Grider 1989), but in our study ascending excitation was abolished with atropine, suggesting that only cholinergic neurons are involved in this pathway. The explanation for this is unclear. It could be due to species variation, but it also could relate to the intensity of stimulation used, as it appears that high intensity stimuli are required to elicit tachykinin-mediated ascending excitation (Grider 1989).

The BD-induced ascending excitatory responses seen in CSM in the current experiments resemble the spontaneous colonic migrating motor complexes reported by Dickson et al. (Dickson et al. 2010), suggesting that they may involve similar neural pathways. Although we did see rare spontaneous depolarizations with spike bursts in our experiments, these were not characterized further. The excitatory responses reproducibly evoked by BD in the current study were invariably abolished by atropine, whereas a combination of atropine and $\mathrm{NK}_{1}$ and $\mathrm{NK}_{2}$ blockade was required to abolish the colonic migrating motor complexes.

An intriguing observation in the current study was the different ascending responses elicited by NS and BD. In keeping with the law of the intestine, BD evoked only depolarization and APs in the CSM. On the other hand, NS produced a brief purinergic IJP followed by rebound excitation in the CSM. In the LSM there was also a brief IJP following by APs in response to BD, whereas NS produced a more complex response consisting of a biphasic IJP (both purinergic 
and nitrergic) following by APs. The physiological significance of these observed differences between NS and BD initial is unclear. In our preparation, the electrical stimulating site was slightly closer to the recording site than the balloon, therefore it is possible that with NS there is non-specific spread of current causing nonphysiological activation of nerves. Hexamethonium $(500 \mu \mathrm{M})$ did not affect these NS-induced ascending respsones to CSM (data not shown). This could mean that there was antidromic activation of descending axons with release of neurotransmitter from side branches, or that there is a true ascending pathway that does not involve synaptic transmission. It is possible that neural pathways exist that are not active under normal physiological conditions, but are demonstrable with supramaximal electrical stimuli. It is noteworthy that when recording from the same cell, the electrical responses to NS were always much more robust than with BD. Thus, although NS is an excellent tool for evaluating the nature of intrinsic neuromuscular responses and the neurotransmitters involved, the relatively subtle electrical responses seen by distention more likely reflect what actually occurs as part of the normal physiological motor response. Additional pathways demonstrated with NS may modulate the physiological reflex.

In summary, the current study suggests that in the murine distal colon: 1) The ascending response induced by BD differs from that induced by the NS, while NS and BD produce similar descending inhibition; 2) The peristaltic reflex conforms to the "law of the intestine"; 3) Ascending excitation is mediated predominantly by 
a cholinergic pathway, whereas descending inhibition is mediated by purinergic neurotransmission. 


\section{Reference List}

Bayguinov, P.O., Hennig, G.W., and Smith, T.K. 2010. $\mathrm{Ca}^{2+}$ imaging of activity in ICC-MY during local mucosal reflexes and the colonic migrating motor complex in the murine large intestine. J. Physiol. (Lond.) 588: 4453-4474.

Bayliss, W.M., and Starling, E.H. 1899. The movements and innervation of the small intestine. J. Physiol. (Lond.) XXIV: 99-143.

Bayliss, W.M., and Starling, E.H. 1900. The movements and innervation of the large intestine. J. Physiol. (Lond.) 26: 107-118.

Christensen, J., Fang, S., and Rick, G.A. 1995. NADPH-diaphorase-positive nerve fibers in smooth muscle layers of opossum esophagus: gradients in density. J. Auton. Nerv. Syst. 52: 99-105.

Ciccocioppo, R., Onori, L., Messori, E., Candura, S.M., Coccini, T., and Tonini, M. 1994. Role of nitric oxide-dependent and -independent mechanisms in peristalsis and accommodation in the rabbit distal colon. J. Pharmacol. Exp. Ther. 270: 929937.

Costa, M., Furness, J.B., Pompolo, S., Brookes, S.J., Bornstein, J.C., Bredt, D.S., et al. 1992. Projections and chemical coding of neurons with immunoreactivity for nitric oxide synthase in the guinea-pig small intestine. Neurosci. Lett. 148: 121- 
125.

Dickson, E.J., Heredia, D.J., McCann, C.J., Hennig, G.W., and Smith, T.K. 2010. The mechanisms underlying the generation of the colonic migrating motor complex in both wild-type and nNOS knockout mice. Am. J. Physiol. 298(2): G222-32.

Gallego, D., Gil, V., Aleu, J., Martinez-Cutillas, M., Clave, P., and Jimenez, M. 2011. Pharmacological characterization of purinergic inhibitory neuromuscular transmission in the human colon. Neurogastroenterol. Motil. 23: 792-e338.

Gallego, D., Gil, V., Martinez-Cutillas, M., Mane, N., Martin, M.T., and Jimenez, M. 2012. Purinergic neuromuscular transmission is absent in the colon of $P_{2 Y 1}$ knocked out mice. J. Physiol. (Lond.) 590: 1943-1956.

Gil, V., Gallego, D., Grasa, L., Martin, M.T., and Jimenez, M. 2010. Purinergic and nitrergic neuromuscular transmission mediates spontaneous neuronal activity in the rat colon. Am. J. Physiol. 299: G158-G169.

Goyal, R.K., and Paterson, W.G. 1989. Esophageal motility. In Hand book of physiology. Edited by S.G. Schultz, J.D.Wood and B.B.Rauner. Oxford University Press, Bethesda, Maryland. pp. 865-908. 
Grasa, L., Gil, V., Gallego, D., Martin, M.T., and Jimenez, M. 2009. $P_{2 Y 1}$ receptors mediate inhibitory neuromuscular transmission in the rat colon. $\mathrm{Br}$. J. Pharmacol. 158: 1641-1652.

Grider, J.R. 1989. Tachykinins as transmitters of ascending contractile component of the peristaltic reflex. Am. J. Physiol. 257: G709-G714.

Grider, J.R., and Makhlouf, G.M. 1986. Colonic peristaltic reflex: identification of vasoactive intestinal peptide as mediator of descending relaxation. Am. J. Physiol. 251: G40-G45.

Hata, F., Ishii, T., Kanada, A., Yamano, N., Kataoka, T., Takeuchi, T. et al. 1990. Essential role of nitric oxide in descending inhibition in the rat proximal colon. Biochem. Biophys. Res. Commun. 172: 1400-1406.

Hirst, G.D., Holman, M.E., and McKirdy, H.C. 1975. Two descending nerve pathways activated by distension of guinea-pig small intestine. J. Physiol. (Lond.) 244: 113-127.

Hirst, G.D., and McKirdy, H.C. 1974. A nervous mechanism for descending inhibition in guinea-pig small intestine. J. Physiol. (Lond.) 238: 129-143.

Hwang, S.J., Blair, P.J., Durnin, L., Mutafova-Yambolieva, V., Sanders, K.M., and Ward, S.M. 2012. $\mathrm{P}_{2 Y 1}$ purinoreceptors are fundamental to inhibitory motor 
control of murine colonic excitability and transit. J. Physiol. (Lond.) 590: 19571972.

Jimenez, M., Clave, P., Accarino, A., and Gallego, D. 2014. Purinergic neuromuscular transmission in the gastrointestinal tract. Functional basis for future clinical and pharmacological studies. Br. J. Pharmacol. 171(19): 43604375 .

Mancinelli, R., Marzio, L., Pescatori, M., Bertuzzi, A., Salinari, S., Serrao, F., et al. 1983. Some parameters of descending inhibition during colonic propulsion. Am. J. Physiol. 245, G307-G312.

Mane, N., Gil, V., Martinez-Cutillas, M., Clave, P., Gallego, D., and Jimenez, M. 2014. Differential functional role of purinergic and nitrergic inhibitory cotransmitters in human colonic relaxation. Acta. Physiol. (Oxf.) 212: 293-305.

Okishio, Y., Takeuchi, T., Fujita, A., Suenaga, K., Fujinami, K., Munakata, S., et al. 2005. Ascending contraction and descending relaxation in the distal colon of mice lacking interstitial cells of Cajal. J. Smooth Muscle Res. 41: 163-174.

Spencer, N.J., Bywater, R.A., Holman, M.E., and Taylor, G.S. 1998. Spontaneous and evoked inhibitory junction potentials in the circular muscle layer of mouse colon. J. Auton. Nerv. Syst. 69: 115-121. 
Spencer, N.J., and Smith, T.K. 2001. Simultaneous intracellular recordings from longitudinal and circular muscle during the peristaltic reflex in guinea-pig distal colon. J. Physiol. (Lond.) 533: 787-799.

Spencer, N., Walsh, M., and Smith, T.K. 1999. Does the guinea-pig ileum obey the "law of the intestine"? J. Physiol. (Lond.) 517: 889-898.

Tonini, M., Onori, L., Lecchini, S., Frigo, G., Perucca, E., and Crema, A. 1982. Mode of action of ATP on propulsive activity in rabbit colon. Eur. J. Pharmacol. 82: 21-28.

Zhang, Y., Carmichael, S.A., Wang, X.Y., Huizinga, J.D., and Paterson, W.G. 2010a. Neurotransmission in lower esophageal sphincter of $W W^{N}$ mutant mice. Am. J. Physiol. 298: G14-G24.

Zhang, Y., and Lang, R.J. 1994. Effects of intrinsic prostaglandins on the spontaneous contractile and electrical activity of the proximal renal pelvis of the guinea-pig. Br. J. Pharmacol. 113: 431-438.

Zhang, Y., Lomax, A.E., and Paterson, W.G. 2010b. $P_{2 Y 1}$ receptors mediate apamin-sensitive and -insensitive inhibitory junction potentials in murine colonic circular smooth muscle. J. Pharmacol. Exp. Ther. 333: 602-611. 
Zhang, Y., and Paterson, W.G. 2002. Role of $\mathrm{Ca}^{2+}$-activated $\mathrm{Cl}^{-}$channels and MLCK in opossum esophageal smooth muscle. Am. J. Physiol. 283: G104-G114.

Zhang, Y., and Paterson. W.G. 2010. Regional differences in descending inhibition to colonic circular smooth muscle (CSM) of $W / W^{N}$ mutant mice. Neurogastroenterol. Motil. 22(Suppl s1): 67.

Zhang, Y., and Paterson, W.G. 2011. Characterization of Ascending Limb of Peristaltic Reflex in Distal Colon of $\boldsymbol{W} / \boldsymbol{W}^{V}$ Wild Type and Mutant Mice. Gastroenterology 140: S375. 
Tables and table legends

Table 1. Ascending responses to electrical nerve stimulation in CSM and LSM of murine distal colon

\begin{tabular}{|c|c|c|c|c|c|c|c|c|c|c|}
\hline & & \multirow[b]{3}{*}{$\begin{array}{l}\text { MP } \\
(\mathrm{mV})\end{array}$} & \multicolumn{4}{|c|}{$1 \mathrm{PS}$} & \multicolumn{4}{|c|}{$4 \mathrm{PS}$} \\
\hline & & & \multicolumn{2}{|c|}{ IJP } & \multicolumn{2}{|c|}{ Slow IJP } & \multicolumn{2}{|c|}{ IJP } & \multicolumn{2}{|c|}{ Slow IJP } \\
\hline & & & $\begin{array}{l}\text { Amplitude } \\
(\mathrm{mV})\end{array}$ & $\begin{array}{l}\text { Duration } \\
\text { (ms) }\end{array}$ & $\begin{array}{l}\text { Amplitude } \\
(\mathrm{mV})\end{array}$ & $\begin{array}{l}\text { Duration } \\
\text { (ms) }\end{array}$ & $\begin{array}{l}\text { Amplitude } \\
(\mathrm{mV})\end{array}$ & $\begin{array}{l}\text { Duration } \\
(\mathrm{ms})\end{array}$ & $\begin{array}{l}\text { Amplitude } \\
(\mathrm{mV})\end{array}$ & $\begin{array}{l}\text { Duration } \\
\text { (ms) }\end{array}$ \\
\hline \multirow{4}{*}{ CSM } & $\begin{array}{l}\text { Control } \\
\mathrm{N}=6\end{array}$ & $-45.4 \pm 3.0$ & $28.7 \pm 2.2$ & $429.8 \pm 39$ & $\mathrm{~N} / \mathrm{A}$ & $\mathrm{N} / \mathrm{A}$ & $34.8 \pm 1.6$ & $859 \pm 72$ & $\mathrm{~N} / \mathrm{A}$ & $\mathrm{N} / \mathrm{A}$ \\
\hline & $\begin{array}{l}\text { Atropine } 3 \mu \mathrm{M} \\
\mathrm{N}=6\end{array}$ & $-43.4 \pm 1.1$ & $31.2 \pm 1.0$ & $520 \pm 80$ & $\mathrm{~N} / \mathrm{A}$ & $\mathrm{N} / \mathrm{A}$ & $\begin{array}{l}37.4 \pm 1.9 \\
*\end{array}$ & $984 \pm 56$ & $\mathrm{~N} / \mathrm{A}$ & $\mathrm{N} / \mathrm{A}$ \\
\hline & $\begin{array}{l}\text { MRS-2500 } 1 \mu \mathrm{M} \\
\mathrm{N}=1\end{array}$ & -40.1 & 2.8 & 1122 & $\mathrm{~N} / \mathrm{A}$ & $\mathrm{N} / \mathrm{A}$ & 16.3 & 1076 & 11.5 & 4146 \\
\hline & $\begin{array}{l}\text { L-NAME } 200 \mu \mathrm{M} \\
\mathrm{N}=1\end{array}$ & -38.4 & 0 & 0 & $\mathrm{~N} / \mathrm{A}$ & $\mathrm{N} / \mathrm{A}$ & 9.4 & 675 & 0 & 0 \\
\hline \multirow{4}{*}{ LSM } & $\begin{array}{l}\text { Control } \\
\mathrm{N}=6\end{array}$ & $-43.1 \pm 1.9$ & $18.2 \pm 1.8$ & $588 \pm 31$ & $0.2 \pm 0.2$ & $403 \pm 403$ & $22.6 \pm 1.8$ & $1022 \pm 83$ & $2.3 \pm 1.2$ & $1618 \pm 742$ \\
\hline & $\begin{array}{l}\text { Atropine } 3 \mu \mathrm{M} \\
\mathrm{N}=6\end{array}$ & $-41.8 \pm 2.1$ & $22.4 \pm 1.7$ & $715 \pm 30.9$ & $0.7 \pm 0.7$ & $380 \pm 380$ & ${ }_{*}^{27.5} \pm 1.4$ & $1216 \pm 54$ & $2.4 \pm 1.1$ & $1317 \pm 645$ \\
\hline & $\begin{array}{l}\text { MRS-2500 } 1 \mu \mathrm{M} \\
\mathrm{N}=6\end{array}$ & $-40.4 \pm 1.6$ & $\begin{array}{l}6.5 \pm 1.4 \\
*\end{array}$ & $820 \pm 106$ & $1.2 \pm 0.9$ & $2158 \pm 1468$ & $\begin{array}{l}12.8 \pm 1.7 \\
*\end{array}$ & $\underset{*}{776 \pm 69}$ & $\begin{array}{l}8.1 \pm 1.3 \\
*\end{array}$ & $\underset{*}{3601 \pm 241}$ \\
\hline & $\begin{array}{l}\text { L-NAME } 200 \mu \mathrm{M} \\
\mathrm{N}=6\end{array}$ & $-39.2 \pm 2.1$ & $1_{*}^{1.7 \pm 0.9}$ & $373 \pm 152$ & ${ }_{*} 0.0 \pm 0.0$ & $\mathrm{~N} / \mathrm{A}$ & $\begin{array}{l}7.6 \pm 1.7 \\
*\end{array}$ & $473 \pm 125$ & $\begin{array}{l}0 \pm 0 \\
*\end{array}$ & $\mathrm{~N} / \mathrm{A}$ \\
\hline
\end{tabular}

Data were presented as mean \pm se; Student $t$-test was used and $p<0.05$ was considered as significant; ${ }^{*}$ represented the significance before and after a drug; N/A: not available. 
Table 2. Ascending responses to balloon distension in CSM and LSM of murine distal colon

\begin{tabular}{|c|c|c|c|c|c|c|c|c|c|}
\hline & & \multicolumn{2}{|c|}{$0.05 \mathrm{ml}$} & \multicolumn{2}{|c|}{$0.10 \mathrm{ml}$} & \multicolumn{2}{|c|}{$0.15 \mathrm{ml}$} & \multicolumn{2}{|c|}{$0.20 \mathrm{ml}$} \\
\hline & & $\begin{array}{l}\text { Junction } \\
\text { Potential } \\
(\mathrm{mV})\end{array}$ & $\begin{array}{l}\text { Duration } \\
\text { (ms) }\end{array}$ & $\begin{array}{l}\text { Junction } \\
\text { Potential } \\
(\mathrm{mV})\end{array}$ & $\begin{array}{l}\text { Duration } \\
\text { (ms) }\end{array}$ & $\begin{array}{l}\text { Junction } \\
\text { Potential } \\
(\mathrm{mV})\end{array}$ & $\begin{array}{l}\text { Duration } \\
\text { (ms) }\end{array}$ & $\begin{array}{l}\text { Junction } \\
\text { Potential } \\
(\mathrm{mV})\end{array}$ & $\begin{array}{l}\text { Duration } \\
\text { (ms) }\end{array}$ \\
\hline \multirow{3}{*}{$\begin{array}{l}\text { CSM } \\
N=6\end{array}$} & Control & $5.0 \pm 1.9$ & $20570 \pm 3157$ & $7.6 \pm 1.7$ & $19389 \pm 2225$ & $5.3 \pm 1.2$ & $21723 \pm 2484$ & $5.5 \pm 1.0$ & $27539 \pm 2392$ \\
\hline & Atropine $3 \mu \mathrm{M}$ & $0.3 \pm 0.3$ & $\mathrm{~N} / \mathrm{A}$ & $0.5 \pm 0.2$ & $N / A$ & $0 \pm 0.3$ & $\mathrm{~N} / \mathrm{A}$ & $\underset{*}{0.5 \pm 0.2}$ & $\mathrm{~N} / \mathrm{A}$ \\
\hline & Control & $1.9 \pm 0.9$ & $257 \pm 101$ & $3.2 \pm 1.9$ & $425 \pm 68$ & $2.7 \pm 2.2$ & $486 \pm 94$ & $3.8 \pm 2.0$ & $691 \pm 166$ \\
\hline \multirow{2}{*}{$\begin{array}{l}\text { LSM } \\
N=6\end{array}$} & Atropine $3 \mu \mathrm{M}$ & $1.6 \pm 0.6$ & $171 \pm 79$ & $2.2 \pm 0.8$ & $181 \pm 83$ & $1.7 \pm 1.0$ & $251 \pm 115$ & $2.5 \pm 1.5$ & $226 \pm 105$ \\
\hline & MRS-2500 $1 \mu \mathrm{M}$ & $0.1 \pm 0.1$ & $\mathrm{~N} / \mathrm{A}$ & ${ }_{*}^{0} \pm 0$ & $\mathrm{~N} / \mathrm{A}$ & ${ }_{*}^{0} \pm 0$ & $\mathrm{~N} / \mathrm{A}$ & ${ }_{*}^{0} \pm 0$ & $\mathrm{~N} / \mathrm{A}$ \\
\hline
\end{tabular}

Data were presented as mean \pm se; Student $t$-test was used and $p<0.05$ was considered as significant; * represented the significance before and after a drug; Junction potential represented EJP in CSM, whereas it represented IJP in LSM. N/A: not available. 
Table 3. Descending responses to electrical nerve stimulation in CSM and LSM of murine distal colon

\begin{tabular}{|c|c|c|c|c|c|c|}
\hline & & & \multicolumn{2}{|c|}{$1 \mathrm{PS}$} & \multicolumn{2}{|c|}{4 PS } \\
\hline & & $\begin{array}{l}\text { MP } \\
(\mathrm{mV})\end{array}$ & $\begin{array}{l}\text { Amplitude } \\
(\mathrm{mV})\end{array}$ & $\begin{array}{l}\text { Duration } \\
\text { (ms) }\end{array}$ & $\begin{array}{l}\text { Amplitude } \\
(\mathrm{mV})\end{array}$ & $\begin{array}{l}\text { Duration } \\
\text { (ms) }\end{array}$ \\
\hline & Control & $-43.9 \pm 1.4$ & $23.1 \pm 1.6$ & $428 \pm 11$ & $28.3 \pm 1.4$ & $719 \pm 55$ \\
\hline \multirow[t]{3}{*}{$\begin{array}{l}\text { CSM } \\
N=6\end{array}$} & MRS-2500 $1 \mu \mathrm{M}$ & $-43.3 \pm 1.4$ & $\underset{*}{2.4} \pm 0.2$ & $759 \pm 146$ & ${\underset{*}{*}}^{8.1 \pm 1.9}$ & $634 \pm 77$ \\
\hline & L-NAME $200 \mu \mathrm{M}$ & $-45.9 \pm 1.9$ & $0.4 \pm 0.4$ & $123 \pm 123$ & $4.4 \pm 0.7$ & $475 \pm 33$ \\
\hline & Control & $-46.8 \pm 1.6$ & $19.1 \pm 2.2$ & $495 \pm 23$ & $21.7 \pm 2.3$ & $759 \pm 70$ \\
\hline \multirow{2}{*}{$\begin{array}{l}\mathrm{LSM} \\
\mathrm{N}=6\end{array}$} & L-NAME $200 \mu \mathrm{M}$ & $-45.5 \pm 1.8$ & $20.6 \pm 2.6$ & $491 \pm 37$ & $23.5 \pm 2.3$ & $745 \pm 72$ \\
\hline & MRS-2179 $1 \mu \mathrm{M}$ & $-44.5 \pm 1.5$ & $13.6 \pm 1.5$ & $416 \pm 19$ & ${ }_{*}^{17.8} \pm 1.8$ & $569 \pm 44$ \\
\hline
\end{tabular}

Data were presented as mean \pm se; Student $t$-test was used and $p<0.05$ was considered as significant; * represented the significance before and after a drug; N/A: not available. Drugs were applied in a cumulative manner. 
Table 4. Descending responses to balloon distension in CSM and LSM of murine distal colon

\begin{tabular}{|c|c|c|c|c|c|c|c|c|c|}
\hline & & \multicolumn{2}{|c|}{$0.05 \mathrm{ml}$} & \multicolumn{2}{|c|}{$0.10 \mathrm{ml}$} & \multicolumn{2}{|c|}{$0.15 \mathrm{ml}$} & \multicolumn{2}{|c|}{$0.20 \mathrm{ml}$} \\
\hline & & $\begin{array}{l}\text { Junction } \\
\text { Potential } \\
(\mathrm{mV})\end{array}$ & $\begin{array}{l}\text { Duration } \\
\text { (ms) }\end{array}$ & $\begin{array}{l}\text { Junction } \\
\text { Potential } \\
(\mathrm{mV})\end{array}$ & $\begin{array}{l}\text { Duration } \\
\text { (ms) }\end{array}$ & $\begin{array}{l}\text { Junction } \\
\text { Potential } \\
(\mathrm{mV})\end{array}$ & $\begin{array}{l}\text { Duration } \\
\text { (ms) }\end{array}$ & $\begin{array}{l}\text { Junction } \\
\text { Potential } \\
(\mathrm{mV})\end{array}$ & $\begin{array}{l}\text { Duration } \\
\text { (ms) }\end{array}$ \\
\hline \multirow{3}{*}{$\begin{array}{l}\mathrm{CSM} \\
\mathrm{N}=6\end{array}$} & Control & $15.1 \pm 2.2$ & $861 \pm 209$ & $23.6 \pm 1.5$ & $1484 \pm 166$ & $25.2 \pm 1.4$ & $1480 \pm 121$ & $23.8 \pm 2.5$ & $1430 \pm 337$ \\
\hline & MRS-2500 $1 \mu \mathrm{M}$ & $1.0 \pm 0.5$ & $\mathrm{~N} / \mathrm{A}$ & $\underset{*}{0.8 \pm 0.5}$ & $N / A$ & ${ }_{*} 2.1 \pm 0.4$ & $963 \pm 433$ & ${ }_{*}^{2.3} \pm 0.5$ & $1569 \pm 983$ \\
\hline & L-NAME $200 \mu \mathrm{M}$ & $1.4 \pm 0$ & N/A & $1.6 \pm 0$ & $N / A$ & $2.6 \pm 0$ & $992 \pm 0$ & $3.0 \pm 0$ & $520 \pm 0$ \\
\hline \multirow{3}{*}{$\begin{array}{l}\text { LSM } \\
N=6\end{array}$} & Control & $8.1 \pm 1.1$ & $1235 \pm 192$ & $12.8 \pm 1.0$ & $1035 \pm 171$ & $15.0 \pm 1.5$ & $1271 \pm 190$ & $16.3 \pm 1.9$ & $1426 \pm 184$ \\
\hline & L-NAME $200 \mu \mathrm{M}$ & $7.5 \pm 1.2$ & $1029 \pm 246$ & $10.3 \pm 1.7$ & $893 \pm 142$ & $13.3 \pm 1.7$ & $906 \pm 108$ & $14.7 \pm 3.0$ & $1074 \pm 53$ \\
\hline & $\begin{array}{l}\text { MRS-2179 } \\
10 \mu \mathrm{M}\end{array}$ & $0 \pm 0$ & $0 \pm 0$ & $\underset{*}{2.8} \pm 0.9$ & $\underset{*}{296 \pm 107}$ & $\underset{*}{2.6 \pm 1.3}$ & $\underset{*}{253} \pm 116$ & ${ }_{*}^{1.2} \pm 1.2$ & $\begin{array}{l}\text { * } \\
*\end{array}$ \\
\hline
\end{tabular}

Data were presented as mean \pm se; Student $t$-test was used and $p<0.05$ was considered as significant; * represented the significance before and after a drug; Junction potential represented IJP. N/A: not available or not measured. Drugs were applied in a cumulative manner. 


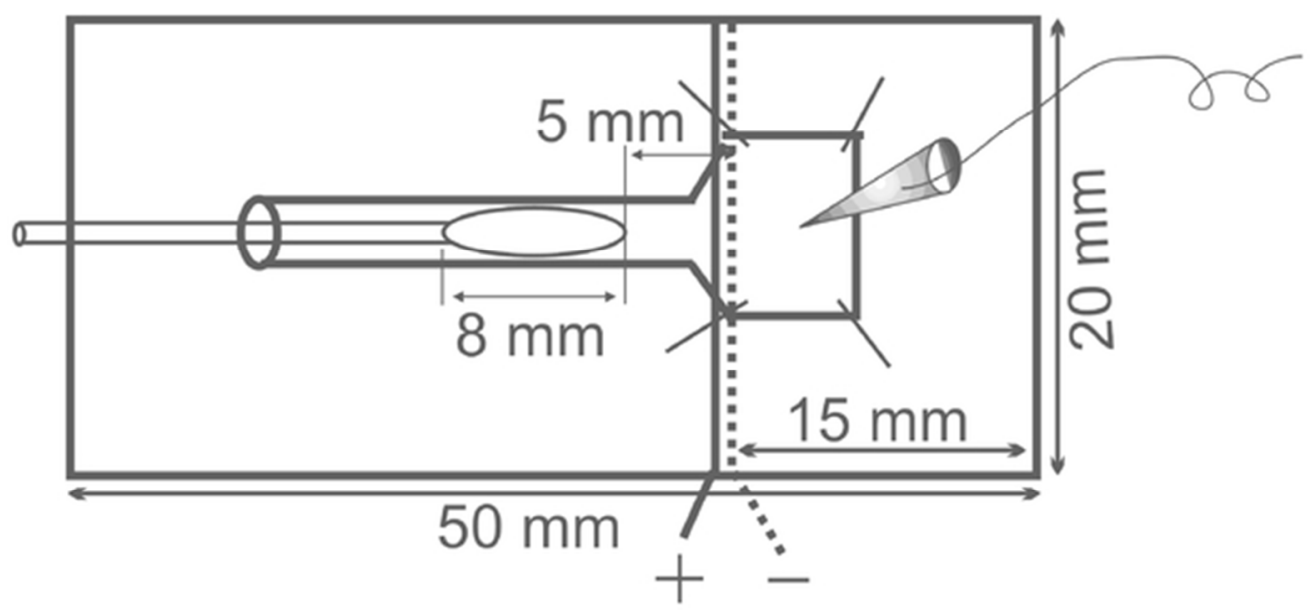

Figure 1. Distal colonic segments from mice were placed in a tissue bath and perfused with oxygenated Krebs' solution at $36^{\circ} \mathrm{C}$. Balloon distention $(0.05,0.10,0.15$ and $0.2 \mathrm{ml}$ ) was performed at the anal/oral end, while an ascending/descending junction potential was recorded from CSM (segment pinned mucosal side up) and LSM (segment pinned mucosal side down) at the proximal/distal end using intracellular electrodes, respectively.

$51 \times 23 \mathrm{~mm}(300 \times 300$ DPI $)$ 
A. a. $0.10 \mathrm{ml}$ balloon distension

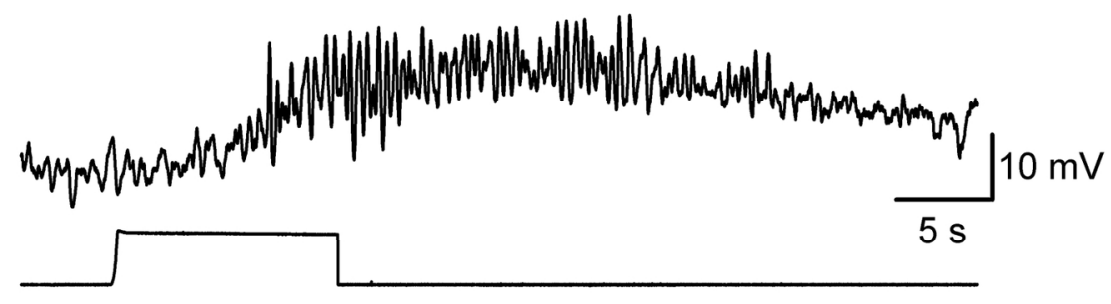

b. $0.1 \mathrm{ml}$ distension in the presence of atropine $(3 \mu \mathrm{M})$

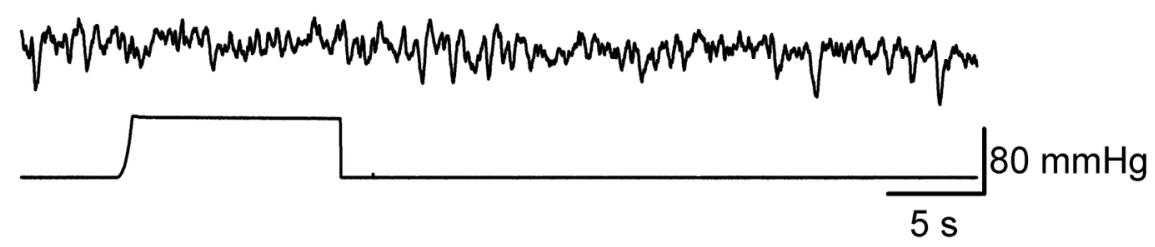
B. a. 4 PS, control
b. 4 PS, atropine
c. Superimposed

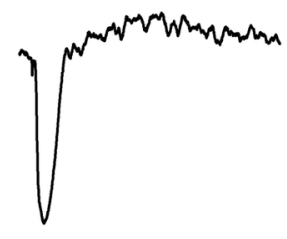<smiles>C=CC=CC=C</smiles>

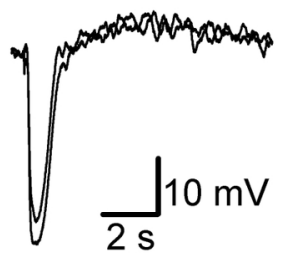

Figure 2. Effects of atropine ( $3 \mu \mathrm{M})$ on the ascending excitatory junction potentals (EJP) in colonic CSM. Panel A: Ascending excitatory junction potentials produced by the balloon. The balloon distention produced a sustained EJP on which APs were imposed (a). The sustained EJPs were abolished by atropine (b). Panel B: Ascending monophasic IJPs induced by nerve stimulation (4 PS). Unlike the excitatory EJP induced by balloon distention, 4 PS of NS produced monophasic IJPs (a), which were potentiated by atropine (b. atropine $3 \mu \mathrm{M}, 10 \mathrm{~min})$. $158 \times 167 \mathrm{~mm}(300 \times 300$ DPI $)$ 
A. Snapshots of responses to balloon distention $(0.10 \mathrm{ml})$

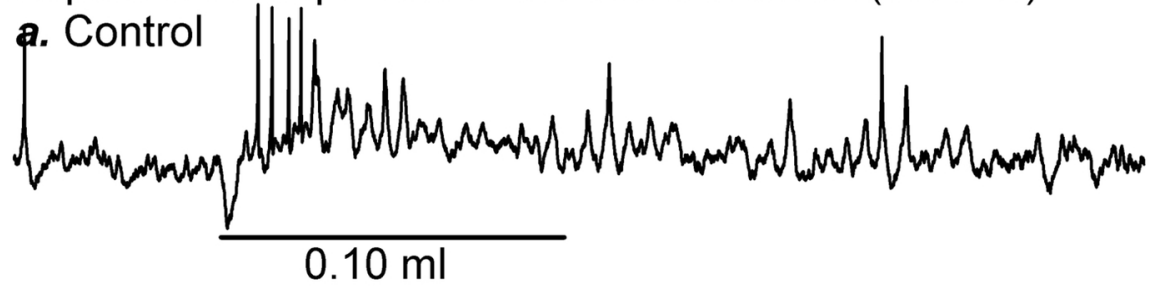

b. Atropine, $10 \mathrm{~min}$
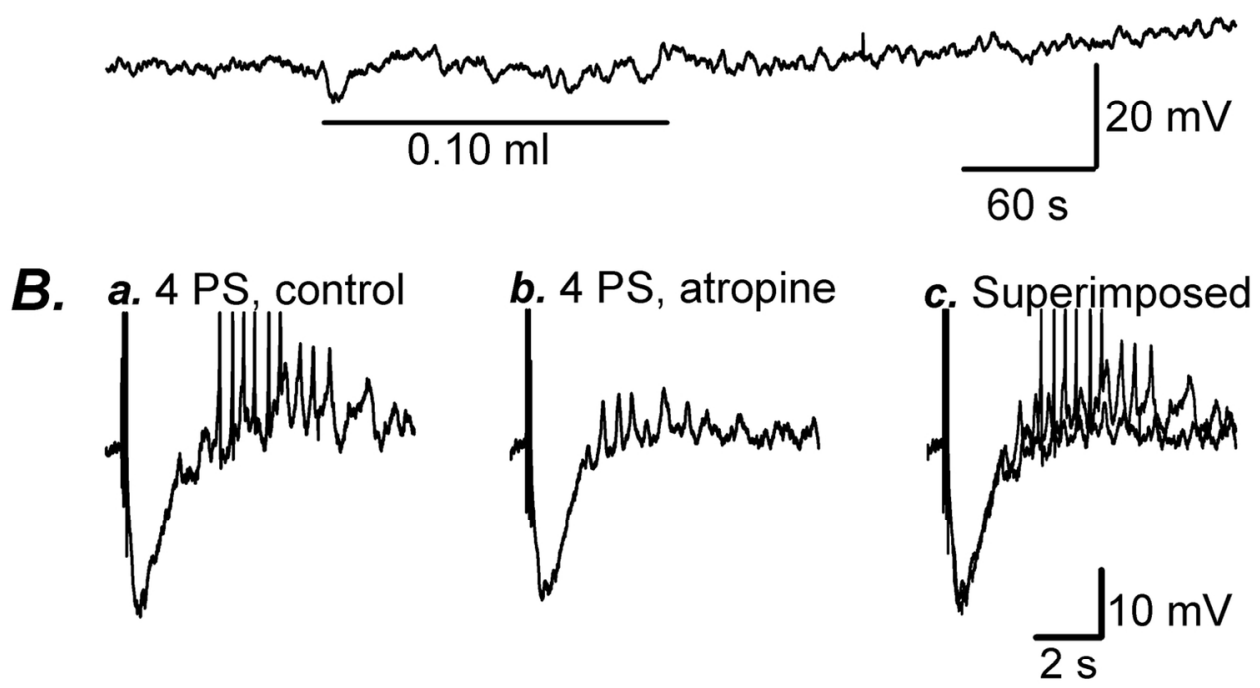

Figure 3. Effects of atropine ( $3 \mu \mathrm{M})$ on the ascending excitatory junction potentals (EJP) in the colonic LSM. A.: Ascending responses of APs and MPs to balloon distention before (a) and 10 min (b) after bath application of atropine. APs were significant less in the mutant than in the wild type mice. B.: Snapshots of the ascending responses to 4 PS of NS in control (a) and $10 \mathrm{~min}$ after atropine $(3 \mu \mathrm{M})$ (b.). c.: Superimposed IJPs. $134 \times 142 \mathrm{~mm}(300 \times 300 \mathrm{DPI})$ 
A. a. $0.10 \mathrm{ml}$ balloon distension

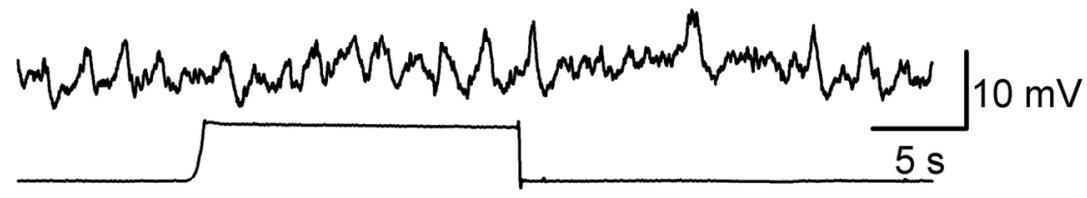

b. $0.1 \mathrm{ml}$ distension after application of MRS-2500 (1 $\mu \mathrm{M} .10 \mathrm{~min})$

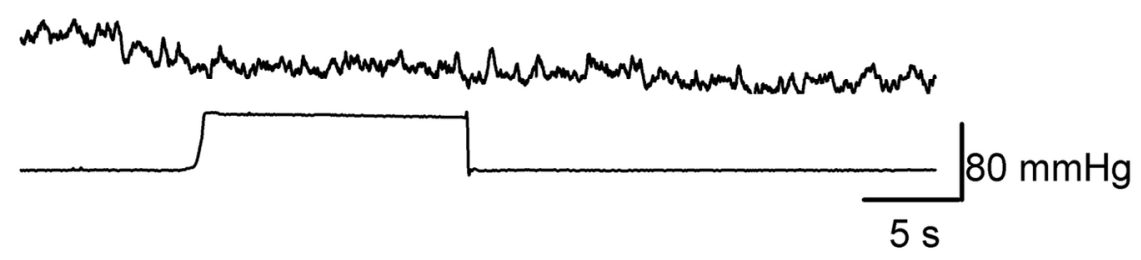

B. a. 4 PS, control

b. 4 PS, MRS-2500

c. Superimposed
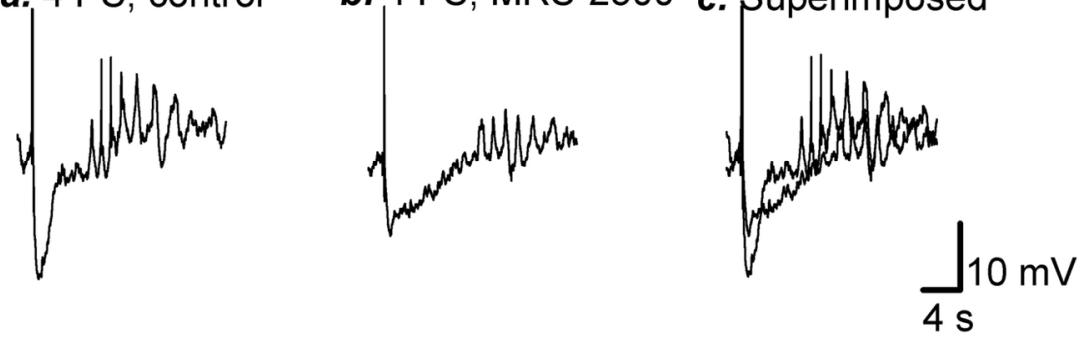

Figure 4. Effects of MRS-2500 $(1 \mu \mathrm{M})$, a specific $P_{2 Y 1}$ antagonist, on the ascending responses evoked by NS (4 PS) and balloon distention $(0.05 \mathrm{ml}-0.15 \mathrm{ml})$ in the LSM in the presence of atropine (3 $\mu \mathrm{M})$. A. depict snapshots of the brief IJPs and balloon pressure in continuous recordings before and 10 min after application of MRS-2500, respectively. B. Superimposed IJPs induced by 4 PS for comparison. a. Control. b. MRS-2500 $1 \mu \mathrm{M}, 10 \mathrm{~min}$. c. superimposed IJPs before and after MRS-2500. MRS-2500 significantly suppressed the fast IJP and enhanced the slow IJP. $136 \times 141 \mathrm{~mm}(300 \times 300$ DPI $)$ 
A. Ascending responses to NS in distal LSM

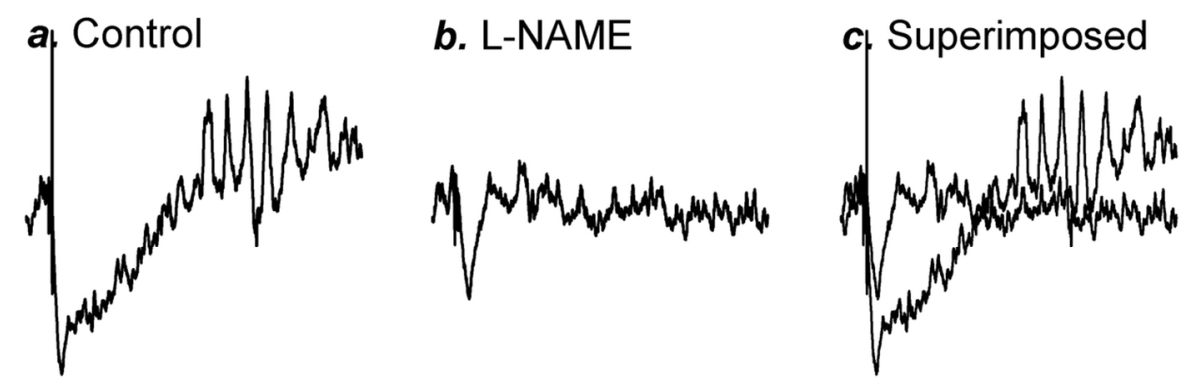

B. Ascending responses to NS in distal CSM

a. Control

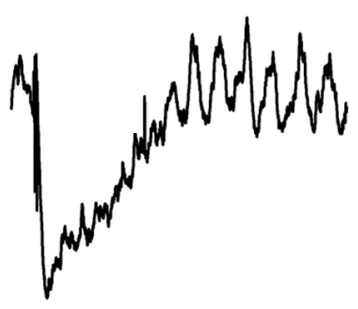

b. L-NAME

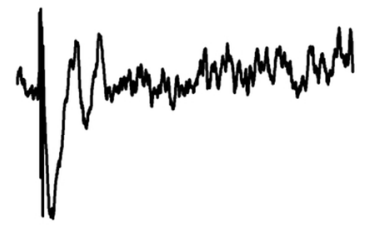

c. Superimposed

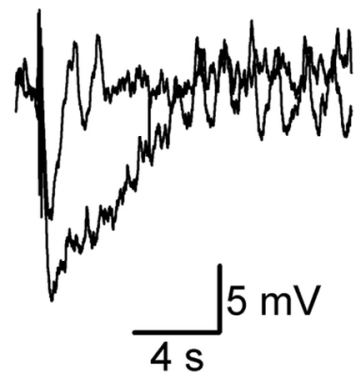

Figure 5. Effects of L-NAME (200 $\mu \mathrm{M}, 15 \mathrm{~min})$ on biphasic ascending IJPs in the LSM and CSM of distal colons in the presence of atropine and MRS-2500 $(1 \mu \mathrm{M})$. A.: Biphasic ascending IJPs produced by 4 PS in distal LSM. B.: IJPs in distal CSM. Application of L-NAME (200 $\mathrm{M}, 15 \mathrm{~min})$ converted the biphasic IJPs (a) to monophasic IJPs (b). C.: Overlaid IJPs before and after L-NAME. $117 \times 101 \mathrm{~mm}(300 \times 300 \mathrm{DPI})$ 
A. Desecending responses to $0.10 \mathrm{ml}$ balloon distensions in CSM
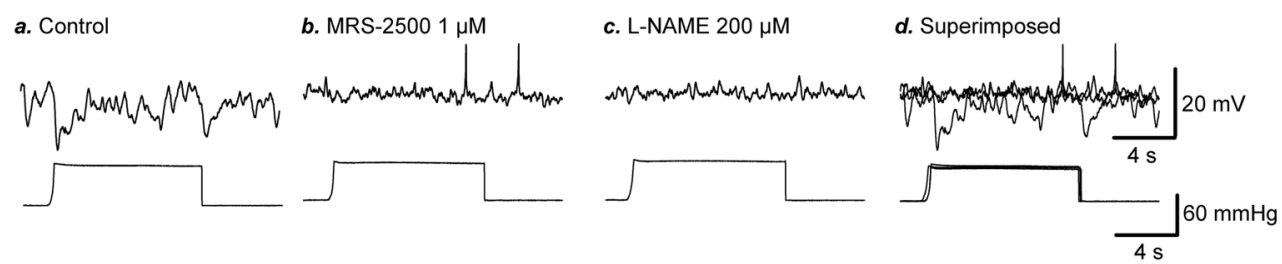

B. Desecending responses to 1 \& 4 PS NS in CSM a. Snapshots of desecending responses to NS of 1 PS $\begin{array}{ll}\text { 1. Control } & \text { 2. MRS-2500 } 1 \mu \mathrm{M}\end{array}$

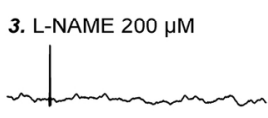

4. Superimposed
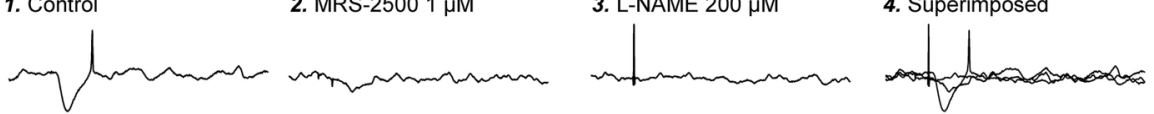

b. Snapshots of desecending responses to NS of 4 PS
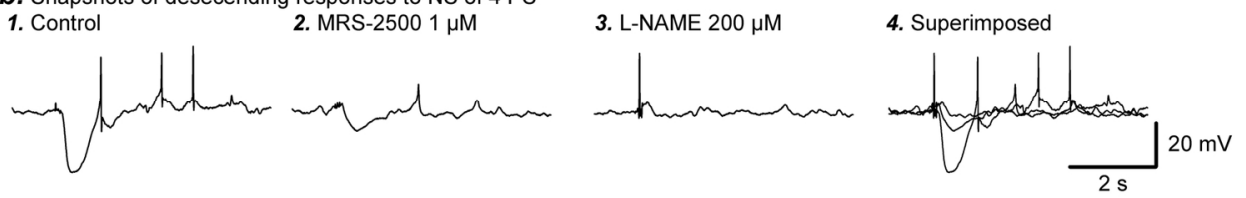

Figure 6. Blockade of the descending inhibitory responses to NS and BD by MRS-2500 and L-NAME in the CSM. A. Snapshots of descending IJPs and balloon pressure before (a.) and after bath application of MRS-

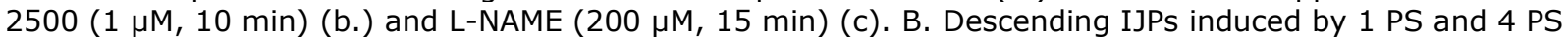
before (1) and after application of MRS-2500 (1 $\mu \mathrm{M}, 10 \mathrm{~min})(2)$ and L-NAME (200 $\mu \mathrm{M}, 15 \mathrm{~min})(3)$. $155 \times 96 \mathrm{~mm}(300 \times 300$ DPI $)$ 
A. Raw recording of descending responses to NS in CSM

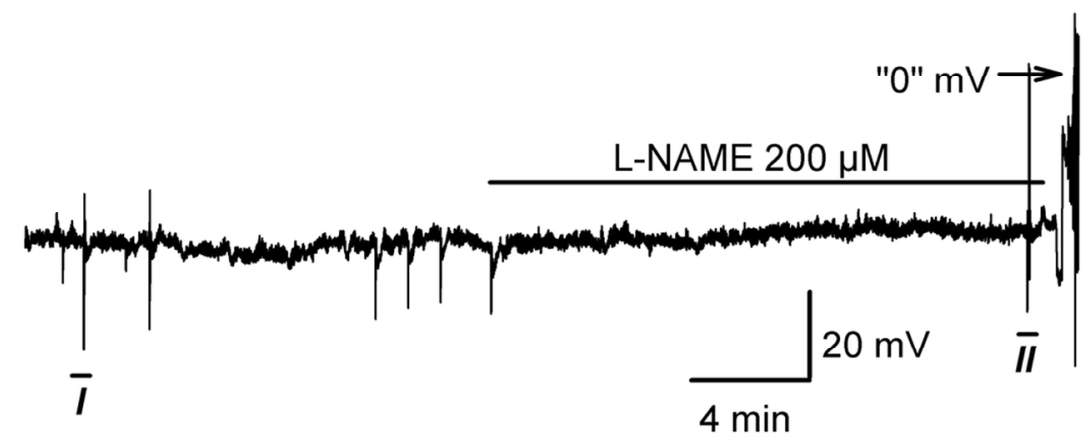

B. Snapshots of IJPs induced by 4 PS

I. Control

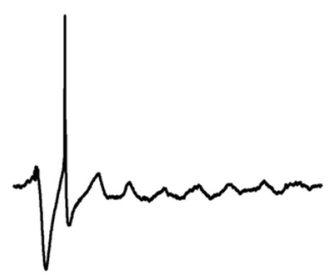

II. L-NAME

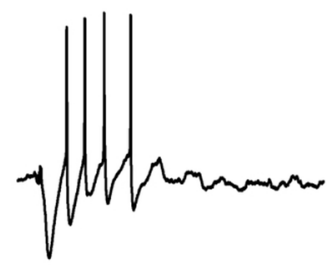

III. Superimposed

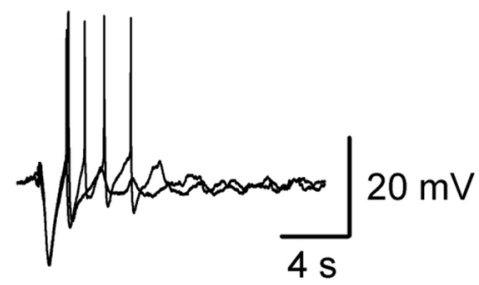

Figure 7. An example of L-NAME (200 $\mu \mathrm{M}, 15 \mathrm{~min})$ produced more APs (descending responses to NS, 4 pulses) in colonic CSM in the presence of MRS-2500 $(1 \mu \mathrm{M})$. Panel A. Monitoring of MPs; Panel B. Snapshot of IJPs induced by 4 NS pulses before and after application of L-NAME. B. III. Superimposed IJPs. 4 pulse NS evoked more rebound APs after application of L-NAME, but did not significantly reduce the MRS-2500 resistant residual IJPs. $108 \times 90 m m$ (300 x 300 DPI) 


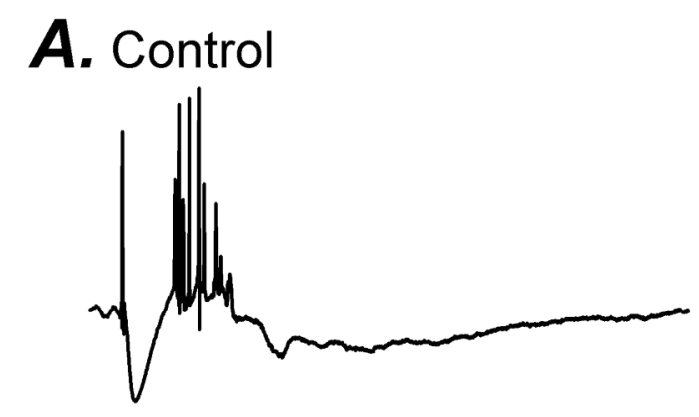

B. L-NAME $200 \mu \mathrm{M}$

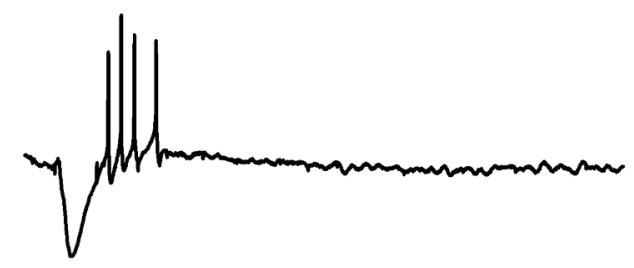

C. Superimposed

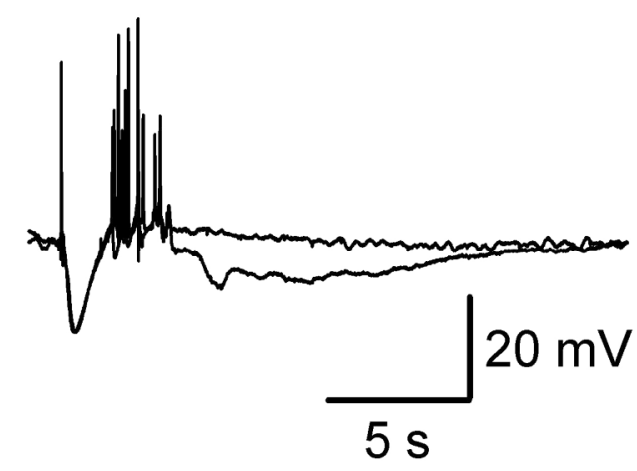

Figure 8. Descending IJPs induced by 4PS NS were not significantly affected by L-NAME in the LSM. A. The IJPs produced by oral NS (4 PS) before (A) and 15 min after L-NAME (B). C. The superimposed descending IJPs for the comparison. $130 \times 265 \mathrm{~mm}(300 \times 300 \mathrm{DPI})$ 
A. Control

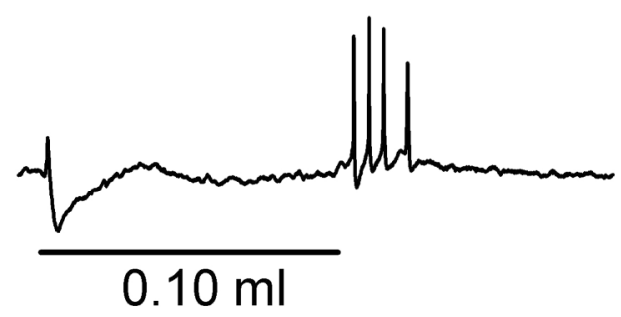

B. MRS-2179 $20 \mu \mathrm{M}$

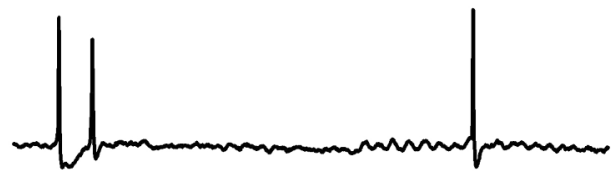

$0.10 \mathrm{ml}$

\section{Superimposed}

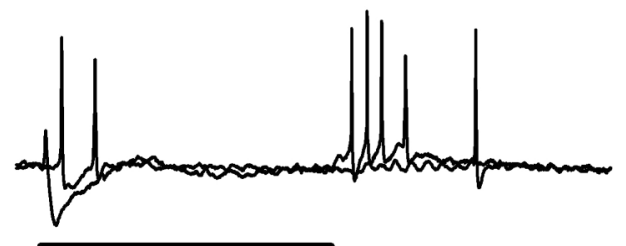

$0.10 \mathrm{ml}$

$20 \mathrm{mV}$

$5 \mathrm{~s}$

Figure 9. Abolition of descending inhibitory responses to BD $(0.1 \mathrm{ml})$ by MRS-2179 in the colonic LSM. Snapshots of the descending IJPs induced by BD $(0.10 \mathrm{ml})$ were displayed in panel A. \& B. before and 10 min after MRS-2179 $(20 \mu \mathrm{M})$. C. The overlapped IJPs before and after application of MRS-2179. Rebound APs after termination of $B D$ were shifted to the onset of $B D$ after application of $P_{2 Y 1}$ receptor blocker, MRS2179.

$131 \times 262 \mathrm{~mm}(300 \times 300 \mathrm{DPI})$ 
A. Raw recording of descending responses to NS and balloon distensions in LSM

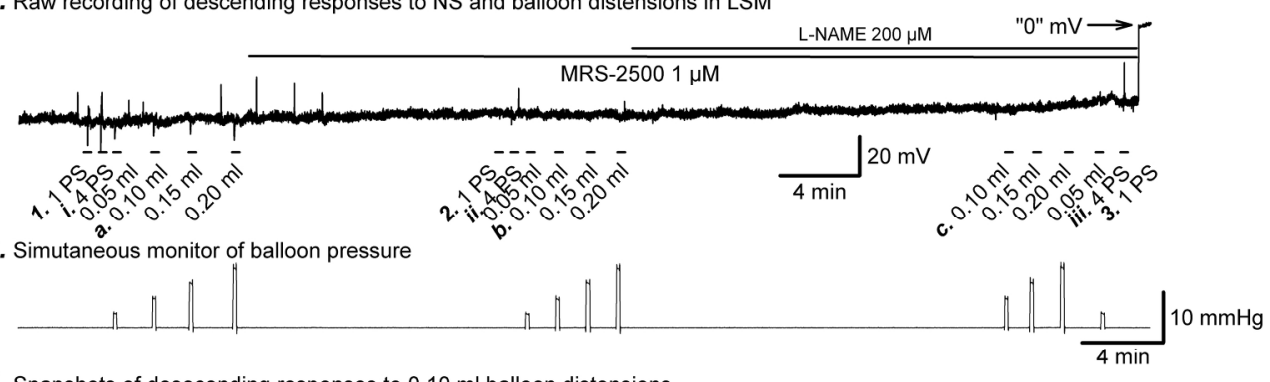

C. Snapshots of desecending responses to $0.10 \mathrm{ml}$ balloon distensions

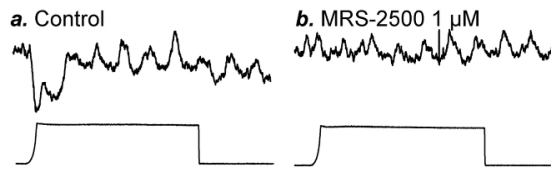

c. L-NAME $200 \mu \mathrm{M}$
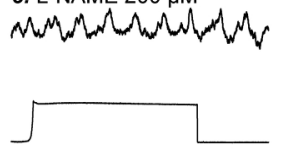

d. Superimposed
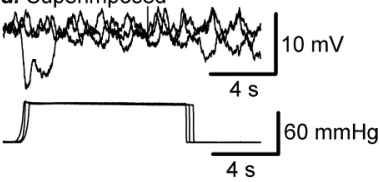

D. Snapshots of desecending responses to NS of 1 PS 1. Control 2. MRS- $25001 \mu \mathrm{M}$

3. L-NAME $200 \mu \mathrm{M}$

4. Superimposed
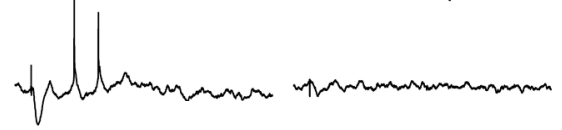

E. Snapshots of desecending responses to NS of 4 PS
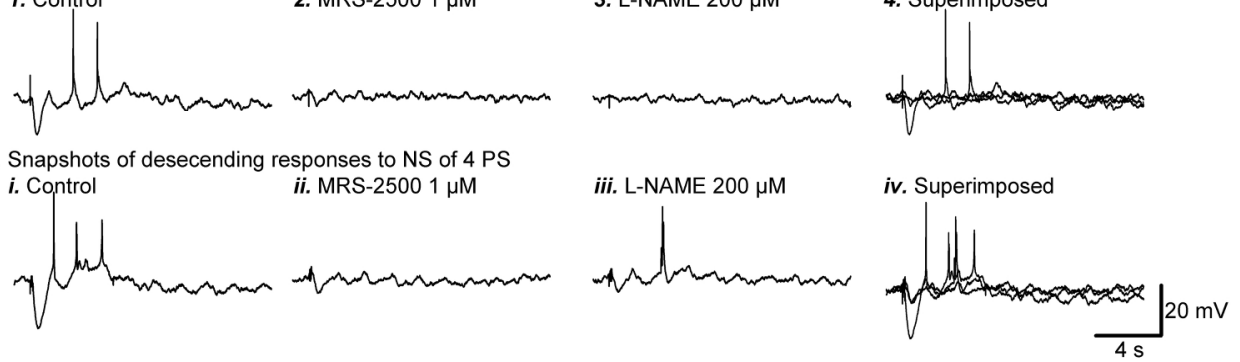

Figure 10. Effects of combined application of MRS-2500 and L-NAME on the descending inhibitory responses to NS and BD in the colonic LSM. A. \& B. Simultaneous raw recordings of membrane potentials and balloon pressure. C. IJPs evoked by BD $(0.10 \mathrm{ml})$ before (a), 10 min after MRS-2500 (1 $\mu \mathrm{M})$ (b.) and further addition of L-NAME (200 $\mu \mathrm{M}, 15 \mathrm{~min})$ (c.). D. \& E. Snapshots of the descending IJPs produced by 1 PS (1. 4.) and 4 PS (i. - iv.) in control and after combined administration of MRS-2500 and L-NAME. $206 \times 168 \mathrm{~mm}(300 \times 300$ DPI) 